\title{
INTERPRETASI ATAS RELASI KOVENANTAL PRA KEJATUHAN: SEBUAH PENGEMBANGAN PEMIKIRAN HERMAN HOEKSEMA
}

\author{
Michael Alexander \\ Gereja Kristen Indonesia Darmo Satelit, Surabaya
}

\begin{abstract}
ABSTRAK: Perdebatan dalam Teologi Kovenan seakan tidak ada habisnya. Meski kovenan di Eden pada umumnya diterima dalam aras Reformed, namun ada pula yang menolaknya, sebutlah John Murray dan Anthony Hoekema. Salah satu alasan penolakan terhadap Kovenan Kerja disebabkan absennya anugerah dalam konsep kovenan sebagai kontrak antara dua belah pihak. Tulisan ini akan menelusuri secara singkat ragam interpretasi mengenai relasi pra kejatuhan, yakni relasi alamiah-anugerah serta natur perjanjian pertama di Eden. Dari tinjauan kesejarahan tersebut terlihat bahwa anugerah terkait dengan relasi kovenantal yang independen dari relasi alamiah. Penulis akan mengargumentasikan bahwa relasi kovenantal bersifat universal dan inheren dalam karya penciptaan, oleh karenanya mencakup relasi alamiah, sehingga anugerah merupakan landasan bagi relasi Allah dengan Adam di Eden. Selanjutnya akan disajikan bahwa landasan anugerah tersebut tertuang dalam bentuk formal Kovenan Penciptaan. Dengan meminjam pemikiran Herman Hoeksema akan disimpulkan bahwa tujuan perjanjian di Eden adalah persekutuan dengan Allah melalui karya penatalayanan ciptaan.
\end{abstract}

KATA KUNCI: Alamiah-anugerah, relasi kovenantal, Kovenan Penciptaan, Herman Hoeksema, penatalayanan.

ABSTRACT: The debate in the Covenant Theology seems to have no end. Although the covenant in Eden generally accepted in Reformed circle, some theologian rejected it, such as John Murray and Anthony Hoekema. One 
reason for the rejection of the Covenant of Work is the absence of grace in the concept of covenant as a contract between two parties. This article will briefly explore the interpretations of the pre-fall relationship between God and man, namely the nature and grace relations, and the nature of the first covenant in Eden. From the historical review, it seems that grace is associated in covenantal relation which is independent of natural relationships. The author would argue that the covenantal relation is universal and inherent in the work of creation. Therefore, grace is the foundation for God's relationship with Adam in Eden. Then it will be presented that grace is embodied in the formal form of the Covenant of Creation. Borrowing from Herman Hoeksema, the conclusion of this writing is that the purpose of the Edenic Covenant is the communion with God through the work of stewardship of creation.

KEYWORDS: Nature-grace, covenantal relationship, covenant of creation, Herman Hoeksema, stewards of creation.

\section{Pendahuluan}

Teologi Kovenan merupakan salah satu warna khas dalam tradisi Reformed. Pengakuan Iman Westminster adalah konfesi Reformed pertama yang memberikan rumusan kovenantal secara eksplisit. Tidak berarti pemikiran pasca konfesi tidak lagi berkembang. Sejumlah teolog kontemporer mencoba untuk menggali kekayaan tradisi tersebut. Hasilnya pun beragam. Misalnya terlihat dalam pemikiran John Murray dan Anthony Hoekema yang keduanya menolak keberadaan kovenan Pra Kejatuhan. ${ }^{1}$ Meski menolak 'kovenan kerja', istilah yang digunakan oleh konfesi, Murray menerima elemen-elemen kovenantal dalam relasi Allah-manusia. Golding

1 Peter Golding, Covenant Theology: The Key of Theology in Reformed Thought and Tradition (Scotland: Mentor, 2008), 109. 
menyebut Murray menganggap istilah Covenant of Life lebih tepat untuk mendeskripsikan relasi tersebut. ${ }^{2}$ Walau demikian, Murray memilih untuk menggunakan istilah Adamic Administration. Penolakan Murray atas istilah 'kerja' disebabkan Ia mempertentangkan antara works dengan grace. Murray menganggap anugerah merupakan landasan operasional dalam keseluruhan relasi Allah-Adam. Demikian pula anggapan Hoekema yang berpendapat bahw penyebutan Kovenan Kerja kurang memperhatikan keberadaan unsur-unsur anugerah. ${ }^{3}$

\section{Ketegangan Meritorious dan Gratious}

Tidak semua teolog Reformed menyepakati keberadaan anugerah pra kejatuhan. Michael Horton menegaskan "[p]rior to the fall, humanity in Adam was neither sinful nor confirmed in righteousness... Therefore, it is anachronistic to require grace or mercy as the foundation of creation and covenant in the beginning..."4 Pandangan Horton meneruskan pemikiran Meredith Kline yang menandaskan,

Grace is of course the term we use for the principle operative in the gospel that was missing from the pre-fall covenant. Properly defined, grace is not merely the bestowal of unmerited blessings but God's blessing of man in spite of his demerit, in spite of his forfeiture of divine blessings. Clearly we ought not apply this term grace to the pre-Fall situation. ${ }^{5}$

Dalam kerangka pikirnya, Kline mempertentangkan anugerah dengan keadilan. Menurutnya, dasar operatif bagi perjanjian pra kejatuhan adalah justice bukan grace. Terlihat ketegangan yang muncul antara pandangan

\footnotetext{
2 Peter Golding, Covenant Theology, 111.

3 Anthony A. Hoekema, Manusia: Ciptaan Menurut Gambar Allah (Surabaya: Momentum, 2012), 154.

4 Michael Horton, Introducing Covenant Theology (Grand Rapids: Baker Books, 2009), 84.

5 Meredith Kline, "Covenant Theology Under Attack," The Upper Register, 2012, diakses 12 September 2014, http://www.upper-register.com/ct_under_attack.html. Penekanan italics oleh penulis.
} 
Kline dengan Murray dan Hoekema. Menurut Kline, jasa perbuatan Adam akan diganjar setimpal dengan perbuatannya berdasarkan keadilan Allah. "Not grace but simple justice was the governing principle in the pre-Fall covenant." Lebih lanjut Kline menyatakan "Adam's obedience in the probation would have been the performing of a meritorious deed by which he earned the covenanted blessings."6

Permasalahan menjadi serius ketika Kline membandingkan Adam dengan Kristus sebagai Adam kedua. Penolakan atas jasa Adam dianggap Kline sebagai penolakan atas jasa Kristus. Kline menegaskan,

if the first Adam could not earn anything, neither could the second. But if the obedience of Jesus has no meritorious value, the foundation of the gospel is gone. If Jesus' passive obedience has no merit, there has been no satisfaction made for our sins. If Jesus' active obedience has no merit, there is no righteous accomplishment to be imputed to us. ${ }^{7}$

Bagi Kline sebelum kejatuhan Adam berada dalam kovenan yang bersifat strictly justice. Ketaatan Adam akan memperoleh imbalan kehidupan kekal. Sebaliknya, pemberontakan Adam diganjar dengan kematian bagi dia dan seluruh umat manusia yang diwakilinya. Pasca kejatuhan, kegagalan Adam digantikan Kristus yang menunaikan Covenant of Work - sama seperti Adam - yang bagi umat tebusan merupakan Covenant of Grace. Kebenaran Kristus yang diperoleh melalui ketaatan-Nya diimputasikan pada umat tebusan. ${ }^{8}$

Setidaknya terdapat dua permasalahan yang melatari ketegangan antara kedua mazhab pemikiran. Pertama adalah perihal interpretasi relasi

\footnotetext{
Ibid.

7 Ibid.

8 Ralph Allan Smith, "Interpreting the Covenant of Works," Covenant Worldview Institute, 2002, diunduh 19 Juli 2014, http://www.berith.org/pdf/Interpreting_the_Covenant_of_ Works.pdf
} 
Allah-manusia di Eden: Alamiah, anugerah atau kesinambungan antara keduanya. Sedangkan permasalahan kedua berkenaan dengan natur kovenan pra kejatuhan: legal atau gracious. Kedua permasalahan berkaitan erat. Sekalipun relasi kovenantal dianggap sebagai relasi anugerah, hal tersebut tidak serta-merta mengakibatkan natur perjanjiaan juga bersifat anugerah.

Untuk mengurai kerumitan permasalahan di atas, tulisan ini akan dibagi dalam tiga bagian: Bagian Pertama mencakup dua sub-bahasan yang memaparkan ragam interpretasi atas relasi Allah-manusia dan atas natur kovenan pra kejatuhan. Selanjutnya, akan diuraikan pemikiran Herman Hoeksema sebagai model alternatif. Terakhir, akan dipaparkan sebuah kajian biblis guna memberikan landasan sekaligus mengembangkan model di atas. Ketiga bahasan akan mendekati permasalahan secara historika, sistematika dan biblika.

\section{Interpretasi Relasi Allah-Manusia}

Distingsi relasi alamiah-anugerah memiliki sejarah panjang. Setidaknya sejak era Medieval pemikiran tersebut telah mengemuka. Sama seperti berbagai pemikiran teologis lainnya, pandangan distingtif tersebut pun berkembang. Dalam dinamikanya, pemikiran kaum Realis yang abstrak didaratkan oleh kaum Nominalis. Akibatnya pandangan sinergistik pun merebak. Maka muncullah berbagai sanggahan dari para teolog NeoAgustinian. Pemikiran mereka terus dipertajam pasca Reformasi hingga akhirnya dirumuskan dalam Pengakuan Iman Westminster.

\section{Pemikiran Realisme Awal}

Thomas Aquinas (1225-74) adalah seorang tokoh yang sangat mempengaruhi pemikiran teologis di Abad Pertengahan. Ia membedakan 
keadaan manusia dalam pure state of nature dan dalam state of grace. ${ }^{9}$ Dalam keadaan 'murni' Adam dapat berelasi dengan Allah. Hal tersebut tetap berlaku pasca kejatuhan yang tidak meniadakan kemampuan natural manusia, termasuk untuk melakukan perbuatan baik. Karlberg menyatakan, "Aquinas taught that the individual's own good works, called 'merits', were the ground of the promised blessing."10 Bagi Aquinas, prevenient grace merupakan keniscayaan agar manusia dapat masuk dalam state of grace dan selanjutnya berelasi secara intim (fruitio) dengan Allah dan memperoleh keselamatan. Colin Smith menegaskan pemikiran Aquinas dengan meyatakan, "Christian is not able to merit eternal life from his own nature, and is in need of grace which takes human effort and makes it meritorious."11

Bonaventura (1221-74) terlihat memiliki pendapat yang serupa. Masih menurut Smith, dikatakan bahwa Bonaventura juga menganggap prevenient grace sebagai prasyarat bagi manusia untuk menjadi ciptaan baru yang dapat memenuhi tuntutan kebenaran Allah. Seseorang memperoleh prevenient grace bukan sebagai imbalan atas upaya yang dilakukannya tetapi semata-mata karena kehendak Allah yang berdaulat. Mengutip kalimat Smith dituliskan "it is simply because God has, through promises, decrees, and covenants, freely condescended to reconcile man to Himself by these means... God has the free will to do so."12

Pemikiran kedua tokoh di atas juga terlihat dalam pandangan John Duns Scotus (1266-1308). Dalam uraian Peter Lillback disebutkan Scotus membedakan antara potentia absoluta dengan potentia ordinata. Lillback menjelaskan,

\footnotetext{
9 Mark. W. Karlberg, "The Original State of Adam: Tensions Within Reformed Theology," Evangelical Quarterly 59, No. 4 (1987): 291-309, diunduh 1 September 2014, Theological Studies. 10 Ibid.

11 Colin D. Smith, "Covenant Theology: A Historical Survey," Colin D. Smith, diunduh pada 6 Juli 2014, http://www.colindsmith.com/papers/covenant\%20Theology-A\%20Historical\%20 Survey.pdf 12 Ibid.
} 
The first represent God's absolute power and sovereignty to do whatsoever He desires free from all limitations except the law of non-contradiction. The second is God's ordained power which is the way God has freely chosen to work. Here, God is bound by laws He has imposed upon Himself. Since they are self-imposed, they are still a result of God's potentia absoluta. ${ }^{13}$

Pembedaan potentia absoluta - potentia ordinata, ketika diterapkan dalam doktrin keselamatan, menyebabkan Allah dapat menyelamatkan siapa pun yang dikehendaki-Nya berdasarkan potentia absoluta. Akan tetapi, berdasarkan potentia ordinata, Allah menetapkan anugerah sebagai prasyarat bagi manusia agar diperkenan-Nya.

Pemikiran Aquinas dan Scotus melahirkan pandangan bahwa anugerah Allah diberikan berdasarkan pada dekrit yang mengikat diri Allah sendiri. ${ }^{14}$ Menggunakan kalimat yang berbeda dapat dikatakan anugerah yang Allah berikan didasarkan pada kovenan, yaitu cara yang ditetapkan Allah sehingga mengikat diri-Nya sendiri. Dari uraian di atas terlihat jelas relasi alamiah dilanjutkan dengan relasi anugerah yakni relasi kovenantal melalui prevenient grace sebagai instrumen.

\section{Nominalisme dan Tanggapan Neo-Agustinian}

Pemikiran para tokoh Realis di atas dikembangkan oleh kaum Nominalis. Mereka menganggap bahwa anugerah merupakan imbalan atas upaya yang dilakukan seseorang. Kaum Nominalis membedakan dua tahap upaya manusia: Meritum de congruo dan meritum de condigno. Meritum de congruo merupakan upaya yang bisa dilakukan oleh setiap orang untuk melakukan bagian yang ditetapkan untuk dilaksanakan. Pemenuhan meritum de congruo menyebabkan Allah mencurahkan anugerah-Nya. Setelah seseorang memperoleh anugerah, maka orang tersebut berada di

\footnotetext{
13 Peter A. Lillback, The Binding of God: Calvin's Role in The Development of Covenant Theology (Grand Rapids: Baker Academic, 2001), 47.

14 Smith, "Covenant Theology"
} 
dalam state of grace. Di sini upaya yang dilakukan oleh seseorang disebut sebagai meritum de condigno, yakni jasa manusia yang diperkenan Allah dengan imbalan keselamatan.

Pemikiran sinergistik tersebut mendapat sanggahan dari mazhab Neo-Augustinian yang diwakili Thomas Bardwardine (1290-1349) dan Johann von Staupitz (1460-1524). Bagi Bardwardine - mengacu pada Smith dikatakan bahwa "divine grace and human merit are totally contrary and that God's decree of election has no point of reference with human activity." 15 Bardwardine menekankan perlunya prevenient grace sebagai prasyarat bagi seseorang agar dapat percaya.

Smith meneruskan uraiannya dengan menjelaskan pemikiran Staupitz. Ia menyatakan bahwa bagi Staupitz,

God has chosen to give grace to the elect, therefore Christ is obligated to secure their redemption. This necessity is the consequence of God's own plan and 'promise,' not man's merit in any sense... God's redemptive promise grows out of His eternal decree to save the elect by giving them the grace to have faith. ${ }^{16}$

Dari kutipan di atas terlihat peran Kristus diperkenalkan dalam karya keselamatan orang-orang pilihan. ${ }^{17}$ Pra kejatuhan, dalam keadaan natural sebagai imago Dei, Adam dapat mencapai fruitio bersama dengan anugerah Kristus. Sedangkan pasca kejatuhan, "good works (nature) retained its function in conjunction with the benefits of Christ's death (race) in the process of salvation."18 Nampak ruang kooperasi bagi manusia bersama dengan karya penebusan Kristus. Pandangan Nominalisme terlihat mempengaruhi

\footnotetext{
15 Ibid.

16 Ibid.

17 Lillback memberikan catatan "[t]he parallel with the covenant of redemption as found in later Reformed Orthodoxy at this point is most remarkable, particularly in the concept of Christ to execute the redemption of the elect." (Binding of God, 54n95).

18 Karlberg, "The Original State of Adam," 294.
} 
pemikiran Staupitz. Karlberg menggunakan istilah ex debito gratia untuk menyimpulkan model anugerah kooperatif tersebut. Ia menulis, "this grace was owed to the elect on grounds of God's covenant obligation made in Christ (ex debito gratia)." 19

\section{Perkembangan Pasca Reformasi}

Meski kovenan pra kejatuhan telah muncul dalam tulisan Agustinus dan elemen-elemen pembentuk doktrin sudah terlihat di era skolastik, namun doktrin Perjanjian Kerja belum berkembang. ${ }^{20}$ Doktrin tersebut baru terlihat secara samar dalam tulisan Olevianus (1536-87) dan menjadi benderang dalam tulisan Robert Rollock (1555?-98). ${ }^{21}$ Rollock - sebagaimana diuraikan Vos - berpendapat,

After God created man in His image, pure and holy, and had written His law in man's heart, He made a covenant with him in which He promised him eternal life on the condition of holy and good works which should answer to the holiness and goodness of the creation, and conform the law of God. ${ }^{22}$

Dari kutipan di atas terlihat Allah berelasi dengan Adam secara natural kemudian secara kovenantal, yakni secara legal. Bagi Rollock Kovenan Pra Kejatuhan merupakan suatu legal atau natural covenant. Janji Allah bagi ketaatan Adam bukan sekadar kebenaran (righteousness) yang sudah dimiliki pada saat penciptaan, tetapi kehidupan kekal. Golding menuliskan, "[i]t is rather the promise of eternal life on the condition of good works performed in the strength of nature." 23 Ia menegaskan,

\footnotetext{
19 Ibid.

20 Louis Berkhof, Teologi Sistematika: Doktrin Manusia, jilid 2 (Surabaya: Momentum, 2009), 6668.

21 Golding, Covenant Theology, 110.

22 Geerhardus Vos, "The Doctrine of the Covenant in Reformed Theology," Redemptive History and Biblical Interpretation: The Shorter Writings of Geerhardus Vos, ed. Richard B. Gaffin Jr.

(Phillipsburg: P\&R Publishing, 1980), 239.

23 Golding, Covenant Theology, 33.
} 
The foundation of this covenant, therefore, was the holy and perfect nature with which man was endowed in creation, whereas in the covenant of grace, life is grounded upon the grace of God in Christ by which the righteousness of another is imputed to the believer. ${ }^{24}$

Pemikiran Rollock serupa para teolog Realis abad ke-13. Akan tetapi dalam keadaan alamiah sekalipun relasi Allah-manusia bersifat kovenantal. Golding menyimpulkan bahwa menurut Rollock, "God speaks nothing to man without covenant." 25 Dalam artian tertentu dapat dikatakan bahwa Rollock memahami hubungan alamiah-anugerah sebagai bagian dari relasi kovenantal. Pemikiran ini akan dikembangkan lebih lanjut di bagian berikut.

Di penghujung abad ke-16 para teolog Reformed telah meninggalkan dikotomi alamiah-anugerah. Pemikiran kaum Nominalis menyebabkan anugerah dipahami secara sinergistik. Sebagai ganti dilakukan pembedaan antara natural order of creation (pre-covenantal order) dan the covenant order. Pandangan ini terlihat dalam pemikiran Francis Junius (1545-1602). Karlberg menyatakan bahwa menurut Junius, Allah Bapa mengikat kovenan dengan Adam dalam kasih Allah Anak. Sebagai ciptaan, terdapat tuntutan ketaatan mutlak bagi Adam untuk memperoleh hidup kekal dan ancaman kematian bagi pemberontakan. Akan tetapi kehidupan kekal diperoleh karena anugerah semata (ex pacto). Dapat dikatakan anugerah diberikan sebagai upah ketaatan. ${ }^{26}$

Karlberg melanjutkan uraiannya dengan menjelaskan pandangan Johannes Cloppenburg (1592-1652). Ia mengatakan Cloppenburg berpendapat bahwa pewahyuan Allah kepada Adam bersifat natural dan supranatural. Relasi kovenantal Allah dengan Adam bukanlah sesuatu yang natural dalam original state of creation. Perlu adanya perendahan diri dipihak Allah untuk mengikat kovenan dengan Adam (divine condescension).

24 Ibid., 34.

25 Ibid., 33.

26 Karlberg, "The Original State of Adam," 297. 
Perendahan diri Allah yang mengikat kovenan dengan Adam selanjutnya mendefinisikan anugerah pra kejatuhan. ${ }^{27}$

Pandangan senada terlihat dalam pemikiran David Dickson (1583?1663). Masih merujuk pada Karlberg, dituturkan Dickson berpendapat bahwa kovenan ditambahkan pada state of nature. Kovenan tidak menggantikan, namun beriringan dengan lex naturae. Hukum alam menuntut ketaatan mutlak Adam sebagai ciptaan dan hamba. Namun melalui pengikatan kovenan Adam dijadikan rekan Allah. ${ }^{28}$

Dari uraian di atas terlihat relasi kovenantal menyerupai donum superadditum dalam Teologi Medieval. Allah berelasi dengan Adam baik secara natural maupun secara kovenantal. Yang pertama dianggap nonredemptive sementara yang kedua bersifat redemptive. Hal ini sejajar dengan pandangan Murray yang berpendapat bahwa relasi kovenantal bersifat menebus. Sebagai konsekuensi, Murray pun menolak kovenan pra kejatuhan karena penebusan sebelum kejatuhan bersifat anakronistik.

Sekelumit latar belakang di atas memberikan gambaran umum mengenai rumusan Pengakuan Iman Westminster:

The distance between God and the creature is so great, that although reasonable creature do owe obedience unto Him as their Creator, yet they could never have any fruition of Him as their blessedness and reward, but some voluntary condescension on God's part, which He has been pleased to express by way of covenant (VII.1). ${ }^{29}$

Terlihat pembedaan antara relasi alamiah dan relasi kovenantal dalam kutipan konfesi di atas. Dalam relasi alamiah manusia tidak dapat menikmati (fruitio) Allah. Meski demikian, manusia memiliki tuntutan ketaatan mutlak sebagai ciptaan Allah. Pengikatan kovenan merupakan

$27 \quad$ Ibid.

28 Ibid., 299.

29 "Of God's Covenant with Man," Center for Reformed Theology and Apologetics, 1996-2016, diakses 29 September 2016, http://www.reformed.org/documents/wcf_with_proofs/ch_VII.html 
prasyarat agar manusia dapat menikmati-Nya. Meminjam istilah Scotus, prasyarat tersebut ditetapkan Allah berdasarkan potentia ordinata. Pergerakan dari relasi alamiah ke relasi kovenantal mempostulasikan keberadaan anugerah. Aquinas, Bonaventura maupun Scotus menggunakan istilah prevenient grace untuk menjelaskan anugerah kovenantal tersebut. Baru dalam perkembangan yang terkemudian, misalnya dalam pemikiran Cloppenburg, perendahan diri Allah diidentifikasi sebagai bentuk anugerah Allah kepada manusia. Lee Irons mengatakan, “God's condescension to overcome this metaphysical chasm is therefore viewd as being 'voluntary' and free..." Ia meneruskan dengan menegaskan "his voluntary act of entering into a covenant with man is viewed as being gracious, a product of undeserved favor." 30

Pemaparan di atas menunjukkan keberadaan anugerah sebelum kejatuhan dalam bentuk perendahan diri Allah yang mengikat kovenan dengan manusia. Sampai di sini anugerah hanya berkenaan dengan pengikatan kovenan. Belum terlihat keberadaan anugerah dalam relasi natural antara Allah dengan manusia. Selanjutnya pembahasan akan memasuki sub bahasan kedua di mana akan kembali dilakukan survei tentang natur perjanjian pertama.

\section{Natur Perjanjian Penciptaan}

Konfirmasi anugerah dalam pengikatan kovenan pra kejatuhan tidak secara serta-merta menjadikan natur perjanjian bersifat anugerah. Sebagaimana telah diuraikan di atas, Kline menganggap natur perjanjian bersifat justice di mana ketaatan Adam akan memperoleh imbalan kehidupan kekal. Namun tidaklah demikian menurut A.A.Hodge (1823-86).

30 Lee Irons, “Redefining Merit: An Examination of Medieval Presuppositions in Covenant Theology," The Upper Register, 2012, diakses 12 September 2014, http://www.upperregister.com/ct_gospel/redefining_merit.html. Irons menuliskan "Nearly all the Puritans concurred in the view that whatever good Adam would have received by his obedience was of grace... There was no real merit involved in Adam's relation to God." 
Ia berpendapat bahwa selain bersifat legal, Kovenan Pra Kejatuhan juga bersifat anugerah. Hodge menuliskan,

[i]t was also essentially a gracious covenant, because although every creature is, as such, bound to serve the Creator to the full extent of his power, the Creator cannot be bound as a mere matter of justice to the natural justice to grant the creature fellowship with himself, or to raise him to an infallible standart of moral power, or to crown him with eternal an inalienable felicity. ${ }^{31}$

Karlberg menyatakan bahwa Hodge mendefinisikan "the natural bond between God and Adam in terms of the covenant bond... For Hodge the covenant of creation was both legal and gracious." 32 Disini terlihat pemikiran Hodge menyerupai pandangan Rollock.

Pemikiran tersebut dikembangkan oleh para teolog Belanda. Karlberg menyatakan bahwa Abraham Kuyper Sr. (1837-1920) menegaskan relasi Allah-Adam Pra Kejatuhan bersifat kovenantal. Penciptaan Adam menurut peta-teladan Allah merupakan tindakan kovenantal. Sedangkan tujuan kovenan di Eden adalah agar Adam bergerak dari keadaan mula-mula, posse peccare et mori (bisa berdosa dan mati), menuju non-posse peccare et mori (tidak bisa berdosa dan mati). Dengan kata lain, Adam bergerak dari kemuliaan penciptaan menuju kemuliaan yang lebih tinggi. ${ }^{33}$

Herman Bavinck (1854-1921) memiliki pandangan serupa. "Meskipun Adam diciptakan menurut gambar Allah, ia belum menjadi gambar itu dalam pengertian sepenuhnya, ...." Bavinck melanjutkan, "[k]ondisinya harus berlanjut kepada kemuliaan yang lebih tinggi atau kepada dosa dan kematian." 34 Ia menyatakan bahwa upah pelanggaran adalah kematian

\footnotetext{
31 A.A. Hodge, Outlines of Theology (St. Edmunds: The Banner of Truth Trust, 1999), 310-11.

32 Karlberg, "The Original State of Adam," 302.

33 Ibid., 303.

34 Bavinck, Dogmatika Reformed: Allah dan Penciptaan, jilid 2 (Surabaya: Momentum, 2012), 70809.
} 
sementara ketaatan adalah kehidupan kekal. Bagi Bavinck moralitas merupakan dasar Kovenan Kerja. ${ }^{35}$

Teolog berikutnya adalah Geerhardus Vos (1862-1949). Ia mengembangkan pemikiran Kuyper namun mempertahankan distingsi alamiah-anugerah. Vos menyatakan "[a]ccording to the Reformed view the covenant of works is something more than the natural bond which exists between God and man."36 Dalam keadaan natural,

[Adam] is free to do the good out of his good nature, but he has not yet attained the highest freedom which can do good only. The latter is placed before him as an ideal. The mean of obtaining it is the covenant of works... The image of God within him must be brought out in the full clarity of his consciousness. ${ }^{37}$

Teolog terakhir adalah Louis Berkhof (1873-1957) yang berpendapat bahwa hidup manusia berakar pada kovenan yang diikat Allah dengan manusia. Dengan mengikuti distingsi alamiah-anugerah, ia menganggap hubungan Allah-manusia pada saat penciptaan bersifat natural. Allah berelasi dengan Adam dalam kondisi natural pra kejatuhan (status integritatis). Allah selanjutnya menambahkan hubungan kovenantal atas hubungan natural yang mencakup persyaratan dan kewajiban yang melekat pada manusia sebagai ciptaan. ${ }^{38}$

Dari survei di atas terlihat beberapa teolog mempertahankan relasi alamiah-anugerah, misalnya Vos dan Berkhof. Tetapi ada juga yang meleburkan keduanya menjadi relasi kovenantal, misalnya Hodge dan Kuyper. Meski demikian Hodge menganggap relasi kovenantal bersifat legal. Demikian pula nampaknya Kuyper memahami relasi tersebut. Sifat

35 Ibid., 2:712.

36 Vos, "The Doctrine of the Covenant in Reformed Theology," 244.

37 Ibid.

38 Berkhof, Teologi Sistematika, 2:69-75 
legal merujuk pada tujuan Kovenan Penciptaan, yang menurut Kuyper dan Bavinck adalah untuk mencapai kemuliaan yang lebih tinggi dibandingkan kemuliaan penciptaan. Tentu pemikiran tersebut wajar adanya. Jika Adam lulus ujian, maka kepadanya akan dianugerahkan glorifikasi. Ketaatan sejajar dengan 'iman' pasca kejatuhan - merupakan instrumen anugerah.

Akan tetapi, tidak semua teolog Reformed sepakat dengan pemikiran di atas. Model perjanjian suzerain-vassal dalam kebudayaan Timur Dekat kuno menuntut ketaatan vassal sebagai prasyarat keberlangsungan relasi dengan suzerain alih-alih menerima suatu imbalan. Herman Hoeksema menganggap ketetapan kovenan pra kejatuhan berkenaan dengan tugas penatalayanan semesta. Terdapat perbedaan pandangan mengenai tujuan perjanjian. Perbedaan tersebut pada akhirnya mempengaruhi interpretasi atas natur perjanjian. Berikut uraian pemikiran Herman Hoeksema.

\section{Kovenan Pra Kejatuhan Sebagai Persekutuan Kasih ${ }^{39}$}

Serupa dengan Murray, Hoeksema mengungkapkan ketiadaan Kovenan Kerja baik dalam Belgic Confession maupun Heidelberg Catechism. Konfesi-konfesi awal, disebut Hoeksema, bahkan tidak memegang doktrin imputasi dosa. Baru Pengakuan Iman Westminster yang memuat Kovenan Kerja dan imputasi dosa. Tentunya tidak disangkal apabila terdapat perkembangan pemikiran perihal imputasi dosa. Mulanya transmisi dosa dipahami secara natural. Baru dalam perkembangannya imputasi federal dikaitkan dengan pelanggaran kovenan pra kejatuhan. ${ }^{40} \mathrm{Hal}$ itu menjelaskan absennya doktrin imputasi dosa pada konfesi-konfesi awal.

\footnotetext{
39 Herman Hoeksema, "The Idea of the Covenant" (makalah dipresentasikan pada konferensi Reformed Churces in the United States (RCUS), 1944).

40 Rowland S. Ward, "Some Thoughts on Covenant Theology \& On Justification," Reformed Persepective Magazine 15, No. 20 (May 2013), diakses 5 November 2015, Third Millennium Ministries
} 
Federal Vision merupakan warna dalam teologi Reformed yang menolak baik imputasi dosa maupun imputasi kebenaran Kristus.

Hoeksema memiliki berbagai keberatan terhadap pemikiran relasi kovenantal Allah-manusia sebagai perjanjian legal (contracting party). Ia menyatakan,

All the good man has is a gift of grace, of free and sovereign favor, from his God. Even if he may love and serve his Creator, it is a gift of divine goodness... How, then, can the relation of that creature to his Creator ever be or become an agreement or pact, according to which man may merit something higher than he has already attained, even eternal life? ${ }^{41}$

Terlihat Hoeksema menolak segala jasa atau upaya manusia untuk memperoleh tingkatan yang lebih tinggi ataupun hidup kekal sebagaimana anggapan Kuyper dan Bavinck. Hoeksema bahkan menolak perendahan diri Allah - sebagaimana dirumuskan konfesi Westminster - memungkinkan pengikatan perjanjian antara Allah dengan manusia sehingga melalui jasanya Adam dapat memperoleh kehidupan kekal. Hoeksema secara eksplisit menyatakan,

it does not, and can never mean that by keeping God's percepts man in the state of righteousness could attain that higher state which is called life eternal, and which is attainedable only through the Son of God. ${ }^{42}$

Engelsma menjelaskan bahwa Hoeksema menolak segala unsur meritum dalam Perjanjian Kerja tanpa menyangkal adanya relasi kovenantal di Eden,

Hoeksema was one with the Reformed traditions in viewing the relationship between God and Adam as a covenant. What he rejected were the teaching that

41 Hoeksema, "The Idea of the Covenant." Penekanan italics oleh Penulis.

42 Ibid. Penekanan italics oleh Penulis. 
that covenant was a conditional agreement and especially that Adam's obedience in the covenant was (or, would have been) meritorious. ${ }^{43}$

Dapat ditegaskan bahwa Hoeksema menolak jasa Adam dalam bentuk apapun, termasuk meritum ex pacto sebagaimana muncul dalam pemikiran Junius maupun teolog-teolog lainnya, semisal Meredith Kline. Engelsma menjelaskan, bagi Hoeksema meritum ex pacto sejajar meritum ex congruo dalam teologi Medieval. ${ }^{4}$

Hoeksema memberikan argumentasi penolakannya. Ia menyatakan bahwa ketiga pasal pertama kitab Kejadian tidak menyebutkan mutual agreement antara Allah dengan Adam. Lebih lanjut ditegaskan bahwa anggapan ketaatan Adam akan memperoleh imbalan kehidupan kekal tidak pernah dinyatakan dalam Alkitab. Anggapan tersebut, sebutnya, merupakan deduksi dari ancaman atas ketidaktaatan berupa kematian. Sebagai kesimpulan Hoeksema menegaskan bahwa perjanjian Allah-Adam merupakan Covenant of Friendship yakni "the living bond of fellowship according to which Adam was the friend-servant of God, set over God's entire earthly house, so that all things must serve him that he might serve his God." 45 Bagi Hoeksema, kovenan di Eden merupakan persekutuan kasih (fellowship in love) antara Allah dengan manusia, serupa persekutuan intra-Trinitarian. Sedangkan tujuan persekutuan tersebut - Engelsma menandaskan - adalah agar manusia, selaku sahabat dan hamba Allah, melayani-Nya dengan memerintah dunia sebagai Kerajaan Allah. ${ }^{46}$

43 David J. Engelsma, "The Covenant of Creation with Adam," Protestant Reformed Theological Journal 40, No.1 (November 2006): 3-42, diunduh 16 Oktober 2014, Protestant Reformed Churches in America. Penekanan italics oleh Penulis.

44 Ibid.

45 Hoeksema, "The Idea of the Covenant"

46 Engelsma, "The Covenant of Creation with Adam," 32. 


\section{Menuju Konvergensi Teologis}

Keseluruhan uraian di atas menunjukkan bahwa interpretasi terhadap relasi alamiah-anugerah - yang di era selanjutnya disebut relasi alamiahkovenantal - sangat mempengaruhi pandangan tentang natur relasi Allahmanusia di Eden. Uraian selanjutnya akan merelasikan hubungan alamiahanugerah secara dinamis dibawah hubungan kovenantal. Relasi alamiah akan dilihat sebagai keberadaan ciptaan di dalam natur ontologis. Sedangkan relasi anugerah akan dilihat sebagai wahyu yang memformalkan hakikat ontic tersebut.

Untuk memberikan landasan argumentatif bagi pendapat di atas, pertama akan diargumentasikan karya penciptaan sebagai tindakan kovenantal Allah-semesta melalui pendalaman teks Yeremia 33:19-26. Selanjutnya akan diargumentasikan keberadaan anugerah yang inheren dalam karya penciptaan dengan meninjau Kejadian 1-2 sebagai dokumen perjanjian. Dalam bagian yang sama akan diusulkan tujuan perjanjian adalah supaya manusia melayani Allah dengan memerintah dunia sebagai Kerajaan Allah selaku sahabat dan hamba-Nya alih-alih memperoleh imbalan kekekalan yang sudah menjadi milik Adam sebelum kejatuhan. Terakhir akan dilakukan tinjauan singkat Perjanjian Allah-Nuh sebagai kontinuasi Kovenan Penciptaan pasca kejatuhan. Akan disimpulkan bahwa Perjanjian Penciptaan memiliki natur yang sama dengan Perjanjian Nuh yaitu sebagai common grace covenant.

\section{Karya Penciptaan Sebagai Tindakan Kovenantal}

Yeremia 33:19-26 merupakan salah satu bagian Alkitab yang mengaitkan perjanjian Allah dengan siang dan malam dengan Perjanjian Daud. Berikut kutipan ayat 20-21 dari pasal tersebut: 
Beginilah firman TUHAN: Jika kamu dapat mengingkari perjanjian-Ku dengan siang dan perjanjian-Ku dengan malam, sehingga siang dan malam tidak datang lagi pada waktunya, maka juga perjanjian-Ku dengan hamba-Ku Daud dapat diingkari,...

Teks di atas kerap memunculkan perdebatan perihal rujukan frase "perjanjian-Ku dengan siang dan perjanjian-Ku dengan malam." Setidaknya terdapat dua pandangan mengenai hal ini. Williamson, sebagaimana dikutip Gentry, memahami frase tersebut dengan mengacu pada perjanjian Allah dengan Nuh (Kejadian 8:22). ${ }^{47}$ Sedangkan Robertson berpendapat bahwa frase tersebut mengacu pada Kovenan Penciptaan. ${ }^{48}$ Guna mendukung argumennya, Robertson mengaitkan nats di atas dengan Yeremia 31:35 sebagai berikut: "Beginilah firman TUHAN, yang memberi matahari untuk menerangi siang, yang menetapkan bulan dan bintang-bintang untuk menerangi malam, ..." Tidak dipungkiri bahwa dalam ayat ini kata 'perjanjian' tidak muncul sebagaimana dalam Yeremia 33:20. Akan tetapi (LAI: 'menetapkan') digunakan sebagai padanan דִִּ̣רִית

Robertson menunjukkan bahwa kata 'matahari, 'bulan' dan 'bintang' hanya terdapat dalam narasi penciptaan (Kejadian 1:16) dan tidak muncul dalam perjanjian Allah dengan Nuh. Oleh karenanya Robertson menyimpulkan Yeremia 31:35 mengacu pada Perjanjian Penciptaan. Demikian pula dengan Yeremia 33:22 karena alur argumentasi dan paralelisme kedua pasal yang terkait erat.

Bertolak dari uraian di atas, pembedaan alamiah dan anugerah sah untuk dipahami dalam kerangka relasi kovenantal antara Allah dengan semesta yang mencakup manusia sebagai microkosmos didalamnya. Tindakan kovenantal Allah untuk menciptakan manusia menurut GambarNya menyiratkan natur ontologis manusia sebagai penatalayan semesta

47 Peter J. Gentry and Stephen J. Wellum, Kingdom through Covenant: A Biblical-Theological Understanding of the Covenants (Wheaton: Crossway, 2012), 220.

48 O. Palmer Robertson, The Christ of the Covenant (Phillipsburg: P\&R, 1980), 20-21.

49 Ibid. lih. I.Raj.11:11, II.Raj.17:15, Mzm.50:16, 105:10 
(relasi alamiah). Bavinck menggunakan istilah microtheos. ${ }^{50}$ Dalam konteks Kejadian 1, Gambar Allah tersebut secara khusus mengacu pada peran pengaturan (rule, dominion) manusia atas realitas ciptaan. ${ }^{51}$ Collins mengutip pendapat Delitzsch - menegaskan bahwa dominium terrae bukan konten tetapi konsekuensi penciptaan manusia sebagai imago Dei. ${ }^{52}$

Pemikiran di atas didukung tata-bahasa Ibrani. Verba pertama dalam

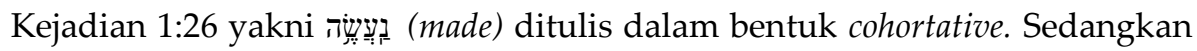
verba kedua יוירָּו (rule, dominate) memakai bentuk imperfect. Menurut Gentry "grammarians of Hebrew agree that this particular sequence (cohortative followed by imperfect) marks purpose or result." 53 Berdasar kajian di atas tepat jika LAI menerjemahkan partikel waw pada verba kedua sebagai 'supaya' seperti terlihat dalam Kejadian 1:26, "Baiklah Kita menjadikan manusia menurut gambar dan rupa Kita, supaya mereka berkuasa..." Terjemahan LAI sejajar NIV yang menuliskan, "Let us make mankind..., so that they may rule..." Kesimpulan yang dapat ditarik dengan menggunakan kalimat kausalitas adalah "karena manusia diciptakan sebagai imago Dei, maka manusia mengemban tugas penatalayanan." Selama manusia adalah imago Dei, maka manusia mengemban Mandat Penciptaan. Imago Dei merupakan tanda perjanjian (covenantal sign) dari Kovenan Penciptaan. ${ }^{54}$

Pandangan di atas sejajar pendapat Kuyper yang menyatakan bahwa penciptaan manusia sebagai imago Dei merupakan tindakan kovenantal. Terlihat Kuyper mengasumsikan relasi kovenantal telah terjalin sebelum Mandat Penciptaan diberikan. Oleh karenanya Mandat Penciptaan harus dilihat sebagai dimensi epistemic yang menjelaskan natur ontic manusia alih-

\footnotetext{
50 Bavinck, Dogmatika Reformed, 2:706.

51 W. Robert Godfrey, God's Pattern for Creation: A Covenantal Reading of Genesis 1 (Phillipsburg: P\&R, 2003), 56.

52 C. John Collins, Genesis 1-4: A Linguistic, Literary and Theological Commentary (Phillipsburg: P\&R, 2006), 66.

53 Gentry and Wellum, Kingdom through Covenant, 188.

54 Ibid., 167.
} 
alih dilihat sebagai inisiasi perjanjian. Dalam bagian selanjutnya kerangka legal-formal akan dilekatkan pada dimensi epistemik tersebut. Tepatlah pandangan Hoeksema sebagaimana dituliskan Dumbrell,

[Hoeksema] prefer to suggest that the covenant with Adam was something constituted by creation, and consisted in a relationship of living friendship and fellowship, a relationship which had been brought into being when Adam had been created in the image of God, which whatever else it involved, meant a knowledge of God. ${ }^{55}$

Dari kutipan di atas setidaknya terlihat dua hal: Pertama berkenaan dengan karya penciptaan sebagai tindakan kovenantal sebagaimana telah diargumentasikan. Sedang hal kedua berkenaan dengan natur relasional antara Allah dengan manusia selaku ciptaan-Nya. Bahasan inilah yang selanjutnya akan didalami.

\section{Konsekrasi Karya Penatalayanan Sebagai Tujuan Kovenan}

Setelah merumuskan Mandat Penciptaan sebagai dimensi epistemik yang menjelaskan natur manusia sebagai imago Dei. Hal yang kini perlu dirumuskan adalah tujuan perjanjian. Niehaus mengonstruksi Kovenan Penciptaan melalui pembacaan atas Kejadian 1-2 sebagai suatu dokumen perjanjian dan mengusulkan struktur berikut: ${ }^{56}$

$1: 1$

$1: 2-29$

$1: 28 ; 2: 16-17 a$

$1: 31$

$1: 28 ; 2: 3$

$2: 17 \mathrm{~b}$
Title/Preamble "In the beginning God created" Historical Prologue

Stipulations

Witness (God)

Blessing

Curse ("for when you eat of it you will surely die")

55 W.J. Dumbrell, Covenant and Creation: A Theology of Old Testament Covenants (Nashville: Thomas Nelson Publisher, 1984), 45. Penekanan italic oleh penulis.

56 Jeffrey J. Niehaus, "Covenant and Narrative, God and Time," Journal of the Evangelical Theological Society 53, No.3 (September 2010): 535-59, diunduh 28 Desember 2015, Evangelical Theological Society. Struktur tersebut didasarkan atas pembacaan kanonik yang mengasumsikan Kej.1-2 sebagai bagian yang utuh. 
Dari struktur di atas dapat dilihat dokumen Perjanjian dimulai dengan kalimat "Pada mulanya Allah menciptakan langit dan bumi." Dalam kebudayaan Timur Dekat kuno, Allah pencipta dianggap sebagai suzerain atau penguasa atas segala sesuatu. ${ }^{57}$ Perjanjian pertama bersifat universal. Secara implisit Adam berperan sebagai wakil federal bagi seluruh umat manusia di hadapan Allah Sang Suzerain. Bagian berikutnya adalah historical prologue. Bagian ini umumnya mencatat hubungan antara kedua belah pihak yang mengikat perjanjian. Narasi Kejadian 1:2-29 mencatat karya kreatif Allah bagi vassal. Karya kreatif tersebut mencakup penciptaan manusia sebagai mandataris Allah yang mengemban Mandat Penciptaan (Kejadian 1:26-28). Seperti telah disebutkan, fungsi tersebut melekat pada natur manusia. Mandat Penciptaan menegaskan natur tersebut secara formal. Dengan mengikut struktur di atas terlihat bahwa tugas penatalayanan semesta merupakan ketetapan positif perjanjian (Kejadian 1:28). Terakhir, Kovenan Penciptaan mencatat sanksi yang akan dijatuhkan apabila terjadi pelanggaran atas perjanjian.

Dari kalimat pembuka perjanjian terlihat sifat monopleuric di mana Allah berperan selaku inisiator perjanjian yang menyerahkan karya kreatifNya dibawah penatalayanan vassal. Asimetrisitas ini menunjukkan natur anugerah perjanjian. Natur tersebut semakin jelas terlihat dari ketercakupan Mandat Penciptaan dalam bagian prolog kesejarahan dokumen perjanjian. Menggunakan kalimat berbeda, vassal harus mengingat bahwa tugas penatalayanan merupakan anugerah yang melatari relasinya dengan suzerain. Keberadaan anugerah pra kejatuhan semakin benderang ketika Mandat Penciptaan tidak dipahami sebagai ketetapan yang ditambahkan tetapi melekat secara ontologis pada natur manusia. Tidak diragukan, anugerah merupakan landasan operatif bagi relasi Allah dengan manusia

57 An ancient Near Eastern reader of Gen.1:1 would most naturally have understood that the verse made a claim for the universal suzerainty of Elohim. (Ibid., n.14) 
pra kejatuhan meski umumnya 'anugerah' dikaitkan dengan murka Allah atas dosa. ${ }^{58}$ John Frame menyatakan "there is no reason to deny that God showed unmerited favor (apart from deserved wrath)... For Adam did not merit or deserve his creation, his surroundings, his vassal kingship, or his fellowship with God." 59 Definisi Frame dengan tepat menyimpulkan penelusuran di atas.

Kembali pada struktur kovenan. Terlihat bahwa dokumen perjanjian tidak mencatat tujuan pengikatan kovenan. Seperti disebutkan, secara historis Perjanjian Penciptaan dianggap memiliki tujuan untuk menuju kemuliaan yang lebih tinggi melalui ujian ketaatan. Memakai kalimat Kuyper, non-posse peccare et mori. Kline menganggap ketaatan Adam pada Perjanjian Penciptaan akan diganjar dengan imbalan hidup kekal. Kegagalan Adam untuk memenuhi tuntutan digenapi oleh ketaatan Adam kedua yakni Kristus. Kline menarik konklusi yang menyatakan bahwa penolakan atas jasa Adam berarti penolakan atas jasa Kristus. Akan tetapi Collins menyatakan bahwa analogi dalam Roma 5:12-21 yang dipergunakan sebagai dasar argumentasi untuk menegaskan sifat meritum dalam Kovenan Penciptaan dapat diperdebatkan. ${ }^{60}$ Nats tersebut bukan merupakan analogi antara Adam dengan Kristus tetapi justru merupakan disanalogi antara keduanya. Hoeksema dan para penerusnya dengan tepat menyatakan bahwa Adam tidak dapat dibandingkan dengan Kristus. Bagaimanapun juga - bahkan dalam status integritatis - Adam merupakan manusia biasa sementara Kristus adalah Pribadi Kedua Trinitas yang semenjak kekekalan ditetapkan untuk menjadi jalan keselamatan melalui karya-Nya. ${ }^{61}$ Teks di

58 "Grace in Protestant theology usually refers to unmerited divine favor where wrath is deserved. On that definition, grace presupposes sin, and there can be no grace before the fall." (John Frame, Systematic Theology: An Introduction to Christian Belief [Phillipsburg: P\&R, 2013], 65n12).

59 Ibid.

60 Collins, Genesis 1-4, 114.

61 Engelsma, "The Covenant of Creation with Adam," 6-7. Engelsma menuliskan "Nor did Hoeksema's denial of the possibility of Adam's meriting imply a denial that the work of Jesus Christ was 
Lukas 3:38 yang menyatakan Adam sebagai anak Allah tidak simetris dengan Yesus sebagai Allah Anak.

Ketiadaan pencatatan imbalan yang diperoleh vassal jika menaati segala syarat dan ketentuan mengindikasian tujuan perjanjian berada di dalam relasi perjanjian itu sendiri. Menggunakan kalimat yang berbeda, tujuan bukan sesuatu yang hendak diraih - misalnya glorifikasi yang diperoleh sebagai imbalan ketaatan atau kerja - tetapi sudah dimiliki dalam perjanjian yaitu relasi antara suzerain dengan vassal (baca: persekutuan). Tidak terdapat unsur meritum dalam relasi ini. Adam bahkan tidak mempertahankan kelanggengan relasinya dengan suzerain melalui kerja penatalayanan apalagi berupaya untuk memperoleh imbalan tertentu. Penganut covenant nomism yang berpendapat demikian. Bahkan pelaksanaan Mandat Penciptaan sekalipun bukan prasyarat relasional. Kutuk tidak dijatuhkan atas kegagalan menjalankan ketetapan tetapi atas pelanggaran larangan (Kejadian 2:16-17). Pendapat ini didukung model suzerainty covenant dalam budaya Timur Dekat kuno yang menuntut kesetiaan vassal sebagai prasyarat relasi dengan suzerain. Apabila Kovenan Penciptaan diterima mengikuti pola perjanjian tersebut, maka dapat dikatakan bahwa ketaatan Adam untuk tidak melanggar larangan merupakan wujud kesetiaan vassal. Secara singkat, wanprestasi terjadi hanya jika larangan perjanjian dilanggar oleh vassal (Kejadian 2:17).

Dengan memperhatikan Mandat Penciptaan sebagai ketetapan Perjanjian Penciptaan, maka dapat disimpulkan bahwa persekutuan Allah dengan Adam di Eden bertujuan agar manusia melayani Allah dengan memerintah dunia sebagai Kerajaan Allah selaku sahabat dan hamba-Nya. ${ }^{62}$ Konsekrasi merupakan wujud kesetiaan vassal yang mempersembahkan

meritorious. There is in this respect a significant difference between the first Adam, who was a mere man, and the second Adam, who is personally the eternal Son of God."

62 Dumbrell, Covenant and Creation, 34-36. 
karya penatalayanannya kepada suzerain. ${ }^{63}$ Konsep sabat yang muncul dalam pembukaan Kejadian 2, dan selanjutnya di perluas dalam Taurat, merupakan penegasan kesimpulan di atas.

\section{Orientasi Temporal Dalam Kontinuasi Kovenan Penciptaan}

Kata bērît pertama muncul di Kejadian 6:18. Menariknya dalam empat kali kemunculannya pada narasi Nuh, kata tersebut selalu berpasangan dengan hēqîm. ${ }^{64}$ Pasangan kata tersebut berbeda dengan kata yang dipergunakan dalam inisiasi perjanjian Allah dengan Abram. Di Kejadian 15:18 pasangan kata yang digunakan adalah kārat bērît. Frase tersebut merupakan pasangan standart yang digunakan untuk mengekspresikan inisiasi pengikatan perjanjian. ${ }^{65}$ Baru ketika Allah menegakkan kembali perjanjian-Nya dengan Abraham pasangan kata yang digunakan adalah hēqîm bērît. ${ }^{6}$ Oleh karenanya Gentry membedakan antara pengikatan perjanjian yang baru dengan penegakkan kembali perjanjian yang telah diikat sebelumnya. Ia menuliskan,

The construction "to cut a covenant" (kārat bērît) refers to covenant initiation while the expression "to establish a covenant" (hēqîm bērît) refers to a covenant partner fulfilling an obligation or upholding a promise in a covenant initiated previously so that the other partner experiences in historical reality the fulfilling of this promise. ${ }^{67}$

Dengan memperhatikan kesimpulan Gentry di atas dapat dikatakan bahwa Perjanjian Nuh merupakan penegakan kembali Perjanjian Penciptaan pasca kejatuhan. Pandangan ini didukung paralel antara kedua narasi.

63 Robertson menuliskan "[t]he Biblical pattern clearly stresses the man's labor always is to be consummated by the consecration of the fruit of his work to the Creator" (The Christ of The Covenant, 80n8). Kata 'konsekrasi' dipergunakan dengan tidak mengacu pada KBBI tetapi pada MerriamWebster Dictionary yang mendefinisikan 'consecrate' sebagai dedicated to a sacred purpose.

$64 \quad$ Kej. 6:18; 9:9, 11, 17.

65 Gentry and Wellum, Kingdom through Covenant, 152.

66 Kej. 17:7, 19, 21.

67 Ibid., 155. 
Waltke mencatat 11 paralel antara Adam dan Nuh serta 7 paralel antara narasi penciptaan dengan kisah Nuh. Bertolak dari paralel-paralel tersebut, Ia menyebut kisah Nuh sebagai penciptaan kembali (recreation). ${ }^{6}$

Tidak dipungkiri terdapat perbedaan signifikan antara Kovenan Penciptaan dengan perjanjian Allah dengan Nuh. Kejatuhan merupakan fakta ketika perjanjian tersebut ditegakkan kembali. Struktur literasi menunjukkan kejahatan manusia membentuk inklusio yang merangkum narasi banjir bah (Kejadian 6:5-6 dan 8:21). Pelaksanaan Mandat Penciptaan beriringan dengan penyebaran kejahatan dan pertambahan jumlah manusia. Dalam keadaan yang demikian Allah menginisiasi perjanjian-Nya dengan Nuh. Natur anugerah jelas terlihat. Tetapi bukan keberadaan anugerah yang hendak diargumentasikan melainkan elemen-elemen perjanjian. Elemenelemen tersebut dicatat dalam Kejadian 9:1-7. Ayat 1 yang di ulang di ayat 7 membentuk inklusio yang memperbaharui tugas penatalayanan yang mulamula Allah berikan kepada Adam. Tugas prokreasi dan multiplikasi ditegaskan kembali. Sementara dominasi atas semesta dibahasakan ulang dalam ayat 2-3. Ketetapan baru yang eksplisit muncul dalam natur kejatuhan adalah perihal tanggung-jawab sosial umat manusia (ayat 5-6).

Kesimpulan yang dapat ditarik dari elemen-elemen perjanjian di atas adalah dengan mengkategorikan perjanjian Allah dengan Nuh sebagai perjanjian yang berorientasi temporalitas alih-alih eskatologis. Caughey yang berada dalam tradisi Kline menyebut perjanjian ini sebagai common grace covenant. ${ }^{69}$ Pendapat Murray yang menganggap perjanjian ini bersifat redemptif sukar dipahami kecuali yang dimaksudkannya adalah keselamatan Nuh dari banjir alih-alih keselamatan eskatologis. 70

68 Bruce K. Waltke, Genesis: A Commentary (Grand Rapids: Zondervan, 2001), 127-29.

69 Chris Caughey, The Tale of Two Adams (California: MGK Press, 2008), 91, Ebook

70 Matthew McMahon, "John Murray's Reformulation of the Covenant of Grace," A Puritan's Mind, diakses 10 September 2014, http://www.apuritanmind/covenant-theology/john-murraysreformulation-of-the-covenant-of-grace-by-dr-c-matthew-mcmahon/ 
Menariknya Frame memberikan pendapat serupa meski mensyaratkan saving grace bagi pemaknaan positif wahyu umum. ${ }^{71}$ Keterbatasan tempat tidak memungkinkan penulis untuk menjabarkan pandangan Murray dan Frame lebih jauh lagi. Hal yang hendak diargumentasikan adalah jika Perjanjian Nuh merupakan penegakkan kembali Perjanjian Penciptaan - di mana Perjanjian Nuh tidak bertujuan konsumasi - maka dapat dikatakan bahwa perjanjian pertama pun tidak bertujuan glorifikasi. Kesimpulan ini menegaskan sub bahasan sebelumnya melalui jalan yang berbeda.

\section{Kesimpulan}

Keberadaan kovenan pra kejatuhan umumnya diterima dalam aras Reformed. Pertentangan muncul dalam natur relasi di Eden serta natur kovenan yang pertama. Uraian historis menyiratkan kesulitan untuk menerima natur anugerah dan distingsi alamiah-anugerah/ kovenantal secara bersamaan. Sekalipun jika anugerah dibedakan dalam kategori umum dan khusus, hal tersebut - hemat penulis terlepas dari pemikiran Hoeksema - terlalu dini untuk dilakukan di Eden. Bertolak dari sana, Hoekema dan Horton serta Kline bertindak konsisten ketika menerima yang satu dan menolak yang lain. Oleh karenanya tulisan ini mengusulkan untuk melihat relasi di Eden sebagai relasi kovenantal yang inheren dalam karya penciptaan dengan anugerah kovenantal Allah sebagai landasan operasional pra kejatuhan. Distingsi alamiah-anugerah pra kejatuhan bukan polarisasi dikotomis tetapi pembedaan perspektif. Yang pertama mengacu pada perspektif ontologis sedangkan yang kedua pada perspektif epistemologis. Pasca kejatuhan, bersamaan dengan relasi antitesis antara benih perempuan dan ular, relasi alamiah-anugerah barulah mengkutub. Proto evangelium

71 "Nature also provides signs for redemptive covenants [Noahic]: the regularity of seasons in Genesis 8:22, the rainbow in Genesis 9:16, and..." (Frame, Systematic Theology, 538-39). 
merupakan inisiasi Perjanjian Anugerah dan iman kepada Sang Benih merupakan batasan kedua relasi.

Dimensi anugerah Kovenan Penciptaan tertuang dalam bentuk formal perjanjian Allah-Adam. Sifat asimeris menunjukkan dimensi tersebut. Sedangkan tujuan kovenan bukan sasaran yang terletak diluar, tetapi merupakan persekutuan yang sudah dimiliki manusia selaku penatalayan semesta, kualitas yang melekat pada natur dirinya, yang terus mengikat secara universal pasca kejatuhan. Bertolak dari tujuan tersebut, tanpa memungkiri bentuk legal-formal perjanjian, relasi Allah-manusia pra kejatuhan merupakan relasi anugerah. Istilah Covenant of Creation yang dipakai Robertson, atau Covenant of Friendship yang dipakai Hoeksema dengan tepat merefleksikan perjanjian di Eden. 